\title{
Early-life circumstances predict measures of trust among adults: Evidence from hunger episodes in Post-War Germany"
}

\section{Iris Kesternich}

KU Leuven, BE-3000 Leuven, Belgium. iris.kesternich@kuleuven.be

James P. Smith

RAND Corporation, CA 90407-2138 Santa Monica, USA. smith@rand.org

Joachim K. Winter

Ludwig-Maximilians-Universität München, DE-80539 München, Germany.winter@1mu.de

\section{Maximiliane Hörl}

Ludwig-Maximilians-Universität München, DE-80539 München, Germany

\begin{abstract}
Can a major shock in childhood permanently shape trust? We consider a hunger episode in Germany after WWII and construct a measure of hunger exposure from official data on caloric rations set monthly by the occupying forces, providing regional and temporal variation. We correlate hunger exposure with measures of trust using data from a nationally representative sample of the German population. We show that individuals exposed to low caloric rations in childhood have significantly lower levels of trust as adults. This finding highlights that early-life experiences can have long-term effects in domains other than health, where such effects are welldocumented.
\end{abstract}

Keywords: preference formation; preference heterogeneity; war shocks; malnutrition Classification codes: D01; D74; J10; J62; N44; Z13 
* Acknowledgements: The data in this publication were made available to us by the German Socio-Economic Panel Study (SOEP) at the German Institute for Economic Research (DIW), Berlin. We thank seminar audiences at Harvard Health Care Policy, the Harvard Center of Population, IUPUI, the University of Stirling, and the Workshop of New Empirical Developments in Health and Labor Markets for helpful comments and suggestions. Financial support through the International Doctoral Program "Evidence-Based Economics" of the Elitenetzwerk Bayern (Hörl); the research funds of KU Leuven (Kesternich); the National Institute on Aging (Smith), and the Deutsche Forschungsgemeinschaft via CRC/TR 190 (Winter), is gratefully acknowledged. Kevin Kloiber and Jannis Stöckel provided valuable research assistance. 


\section{Introduction}

Trust has a decisive role in many human interactions. For example, when we consider whether to engage in some form of cooperation with others, it is crucial whether we believe this person is trustworthy (Gambetta, 2000). Societies with higher levels of trust tend to have better government institutions and thus higher economic growth (La Porta et al., 1997; Knack and Keefer, 1997). Furthermore, measures of trust are important predictors of economic activity in such diverse areas as stock market participation (Guiso et al., 2008) and international trade and investments (Guiso et al., 2009). Not much is known, however, about the underlying determinants of trust and the reasons for the observed heterogeneity among people.

In this paper, we study in a life-course perspective (Elder, 1998) whether a major shock on individual experiences early in life - specifically, the exposure to the experience of hunger predicts trust later in adult life. We construct a measure of exposure to hunger in Germany after the Second World War (WWII) from data on caloric rations that were set monthly by the occupying forces in the four occupation zones. We combine these exposure measures with data from a random sample of the adult German population and document that individuals who were exposed to low caloric rations in their childhood and youth show significantly lower levels of trust many years after the hunger experience.

Our analysis is motivated by a recent wave of research showing that early-life circumstances and shocks, even those experienced in utero, do not only predict adult health outcomes (Barker, 1992, 2004; Almond and Currie, 2011; van den Berg et al., 2015) but also socio-economic outcomes later in life. Adult outcomes affected by such shocks as the experience of war or exposure to prolonged periods of hunger early in life include education and labor market status (Akbulut- 
Yuksel 2014; Goodman et al., 2011; Juerges, 2013; Kesternich et al., 2014), preferences for food consumption (Kesternich et al., 2015), the development of egalitarian motivations (Bauer et al., 2014), and subjective well-being (Bertoni, 2015).'

This study is also related to an emerging literature in economics arguing that the societal and institutional environment and individual experiences over the life course can change preferences and expectations (Fehr and Hoff, 2011; Malmendier and Nagel, 2011, 2016; Black et al., 2015; Malmendier and Shen, 2015). More specifically with respect to social preferences and trust, Putnam et al. (1994) and Bigoni et al. (2015) argue that historical events have shaped preferences for cooperation in Southern and Northern Italy differentially and that the resulting preference heterogeneity can account for the fact that individuals in the South and North react differently to similar institutions and incentives. In addition, East and West Germans have been shown to differ in measures of trust and convergence after reunification has been at most very slow, which has been interpreted as the political system shaping trust (Rainer and Siedler, 2009).

Despite these recent advances, evidence on the determinants of heterogeneity in trust preferences is still scarce. In particular, it has been difficult to link variation in historical events to variation in trust preferences. In this paper, we exploit the natural experiment induced by variations in caloric supply across regions and over time in the years immediately after the end of WWII in Germany to study this link. Our analysis shows that slightly less than one quarter of the difference in levels of trust between East and West Germany go back to the stronger exposure to hunger of East Germans after WWII.

'Hunger has also been shown to have effects in the very short run: In an experimental study, by Aarøe and Petersen (2013) respondents with low glucose levels show stronger support for social welfare. 
The remainder of this paper is structured as follows. In Section 2, we describe the data, the measures of trust and exposure to hunger, and the statistical framework. Section 3 contains the results. We conclude with a discussion of our findings in Section 4.

\section{Methods}

Data

In this research, we focus on Germany because a high share of the German population was affected by regulated food supply during and after WWII - including especially low levels of caloric rations after WWII that have been shown to be associated with severe hunger (Kesternich et al., 2015). Our study relies on the possibility to match measures of childhood exposure to hunger to adult preference measures of trust.

Measures of adult trust are contained in the German Socio-Economic Panel (SOEP), an annual survey of the German population conducted since 1984. The SOEP has the advantage that each wave is representative of the German population. Furthermore, a rich set of background measures, such as biographic and demographic information, education, and employment histories, are available. However, the panel does not contain direct information on the experience of hunger. Therefore, we enrich the SOEP data with historical data on official daily caloric rations during and after WWII. The historical data provide regional as well as temporal variation in caloric restrictions, and we link them to individual-level data in the SOEP using the month of birth and state of residence in childhood.

Further information on the SOEP can be obtained online (http://www.diw.de/en/soep). 
Measures of trust. Survey measures of trust preferences are contained in the 2003 wave of the SOEP. Specifically, respondents were asked for their assessments of the following three statements regarding trust: (A) On the whole one can trust people. (B) Nowadays one can't rely on anyone. (C) If one is dealing with strangers, it is better to be careful before one can trust them. Respondents answer each question on a four-point scale from 1 (totally agree), 2 (agree slightly), 3 (disagree slightly) to 4 (totally disagree). These trust questions are similar to those used in the General Social Survey $^{3}$ and the World Values Survey ${ }^{4}$

For the SOEP, these earlier trust questions have been refined by Naef and Schupp (2009) to address a critique by Glaeser et al. (2000). Glaeser et al. criticize that these earlier measures are "vague, abstract, and hard to interpret." They integrate survey measures of trust with experimental trust games and find that these standard attitudinal questions do not predict actual behavior in these trust experiments (but rather trustworthiness). Naef and Schupp (2009) develop a new survey measure of trust incorporating the three before mentioned questions. In doing so, they concentrate on James Coleman's concept of trust (Coleman, 1990), which considers trust rather as a form of behavior than a personal characteristic or trait. They show that the three trust questions used in the SOEP provide a valid and reliable measure of trust in strangers (in contrast to trust in institutions and known others) and correlate with behavior in an incentivized trust game. In this respect, this form of trust appears especially relevant for human interactions. The behavioral relevance of this trust measure has been shown by Fehr et al. (2002). They combine the three aforementioned questions by means of factor analysis and show that this combined measure is a significant predictor of the

\footnotetext{
. "Generally speaking, would you say that most people can be trusted or that you can't be too careful in dealing with people? - Most people can be trusted / Can't be too careful."

" "Generally speaking, would you say that most people can be trusted or that you need to be very careful in dealing with people? - Most people can be trusted / Need to be very careful."
} 
amount that a first-mover sends to the other player in an incentive compatible trust game. Following Fehr et al. (2002) and Dohmen et al. (2012)we combine the answers to the three survey questions into a single trust measure by principal component analysis and standardize the first principal component. A higher value for this constructed measure is associated with a higher willingness to trust others. We construct these measures for individuals potentially exposed to hunger in childhood.

Measures of childhood exposure to hunger. Since the beginning of WWII, food production and distribution in Germany was organized centrally with yearly updates of caloric rations. Food and many other things could only be bought using food stamps. A food stamp could, for instance, indicate that one would be allowed (among others) to buy four pounds of bread and 62 grams of fat per week, as well as one egg per month. After the end of WWII, the administrations of the four occupation zones (British, U.S., French, and Soviet) separately set levels of caloric rations and updated them monthly. On June 20, 1948 a currency reform took place in the three Western zones leading to an immediate improvement in food supply (Rothenberger, 1980). From 1950, food rationing was completely eliminated in the three Western zones, and recommended levels of about $3000 \mathrm{kcal}$ per day were again achieved. In the German Democratic Republic, however, food supply was still problematic so that food rationing was not abolished before 1956 (Schwarzer, 1995).

Severe famine conditions in Germany were initially reported in the summer of 1945 (Farquharson, 1985), continued through the first years of the Allied occupation, and lasted until 1948. The famine was caused by a combination of supply-side reasons (missing inputs like seeds and fertilizer, missing workforce and machinery as well as losing the pre-war Eastern parts - the so-called "food basket" for Germany), demand-side reasons (increased population through an influx of refugees from the former Eastern parts of the German Reich), breakdowns in trade and transport within 
Germany, and the organization and governance of the occupying governments (see Kesternich et al. 2014 for further information).

Caloric variations varied considerably by occupation zone and time (Kesternich et al., 2015). The agricultural production potential of the occupation zones was very diverse. Since trade between the zones was severely restricted, each zone had to meet its own demand from local production (Schlange-Schöningen, 1955). The agricultural production potential was, in fact, highest in the Soviet Zone, but this was not reflected in the rations, as both in the French and in the Soviet zone large parts of local production were confiscated and distributed to military personnel or sent back to occupying countries (Schlange-Schöningen, 1955). The latter was not the case in the UK and US zones. Thus, until the French zone was united with the two Anglo-Saxon zones, its inhabitants faced a worse nutritional situation (about 200-300 kcal per day less). The Soviet zone was also the strictest in controlling and confiscating food right where it was produced, and given the different political goals and economic means to achieve it, food supply remained problematic for longer, and food rationing was only abolished in 1956. The situation improved more quickly in the US than in the UK zone, as the US zone relied on existent local and decentralized administration.

In this study, we use the monthly area-dependent caloric measures from January 1929 to December 1971 (Kesternich et al., 2015). For the time before 1939 when food supply was not restricted, we use average caloric intake per day from the League of Nations for Germany (Liebe, 1947). From 1939 until the end of WWII, daily caloric rations did not differ by area, and new caloric rations were set in September.

\footnotetext{
${ }^{5}$ Reported and recommended caloric rations were about 3100 kcal per day (Liebe, 1947).
} 
After the end of the war, caloric rations were updated every four weeks in all but the Soviet zone (Schwarzer, 1995). Figure 1 illustrates this source of regional as well as temporal variation in caloric rations by zone that we exploit in our study. Caloric rations dropped significantly in all zones early in 1945, with a most pronounced drop in the French and U.S. zone. It took much longer for the caloric rations to be back at pre-war levels in the Soviet occupation zone.

Official caloric rations are highly consistent with self-reports of experienced hunger (Kesternich et al., 2015). We compared our collected official caloric rations to self-reports on the existence and duration of experienced hunger that are included in SHARELIFE. SHARELIFE is a retrospective life history survey included in the cross-national European panel survey SHARE that, however, does not include any measures of trust. ${ }^{6}$ We observe a clear relationship between the temporal pattern of caloric rations and self-reported hunger. When caloric rations were not restricted yet in 1938, average daily caloric intake was about $3100 \mathrm{kcal}$ while about $1 \%$ of the sample reported hunger. In 1944, caloric rations were set at about $1700 \mathrm{kcal}$ per day and about $10 \%$ of the sample reported hunger. When the caloric rations drop to about $1000 \mathrm{kcal}$ in 1945, we observe a spike in self-reported hunger at about $20 \%$. In 1950, caloric rations were mostly back at pre-war levels (except for the Eastern part) and self-reported hunger decreased to about 5\% (Kesternich et al., 2015). In the SHARELIFE, the raw correlation between a dummy that measures whether a respondent suffered from hunger between ages 0 and 16 and our caloric measure for that age range is 0.271 . When we include zone dummies, age (in years), age squared, urban, male, and a measure of socio-economic status, the coefficient in a linear regression is 0.238 . Thus, for a

\footnotetext{
${ }^{6}$ For a detailed description of SHARE and SHARELIFE see http://www.share-project.org/.
} 
decrease in caloric rations by about $1000 \mathrm{kcal}$, the probability of reporting having suffered from hunger increases by about 24 percent.

As the government and the occupying administrations set caloric rations independently, the sources of restricted food supply were exogenous to the individual. Moreover, we have shown that the exposure to hunger is independent of socio-economic status (Kesternich et al., 2015).

To investigate heterogeneous effects of hunger episodes at different stages of childhood, we generate age-specific average daily caloric intakes that depend on the month of birth as well as residence in childhood. We concentrate on the overall exposure to hunger between ages 0 and 16 and further explore the age ranges 0-3 (infant), 4-7 (child), and 8-16 (youth). For instance, for an individual that was born in January 1940 and has spent childhood in the part of Germany associated with the Soviet zone after WWII, we construct a calorie measure for ages 0-3 taking the average of caloric rations set between January 1940 and December 1943 within this area. In addition, we construct a measure of age-specific variability in daily caloric rations in a similar procedure calculating the standard deviation of the exposed caloric rations at the respective ages - depending again on the month of birth and residence in childhood.

One potential concern with our measure of caloric supply is that there were separate rations for adults and children. Moreover, very young children were breastfed. We did not find any quantitative information on how the combined rations of all family members were shared among them. Thus, as the adult and child rations tend to be highly correlated, either could be used as a proxy for the amount of calories individuals in the age groups relevant for our paper actually received. We decided to use the adult rations because this seems to be easier to compare across regions and over time. 


\section{Statistical analysis}

We estimate ordinary least squares (OLS) regression models in which the dependent variable is the standardized measure of trust obtained from the three survey questions by principal component analysis. To estimate the effect of exposure to hunger in childhood on trust preferences, our key explanatory variables are the average as well as the standard deviation of daily caloric intake at ages 0-16, 0-3, 4-7 and 8-16. We estimate all models using robust SEs clustered by month of birth $\times$ occupation zone at childhood.

We construct our analytic data set from the 2003 wave of the SOEP, which includes the trust measure. We select 7,941 observations of those who participated in this wave; the selection criteria are possible exposure to WWII - that is birth years 1929 to 1955 and being born in Germany or immigrated prior to 1949 ("full sample" hereafter). Exposure to restricted food supply at different ages in childhood varied by residence in the respective occupational zones as well as by month of birth. We merge the SOEP observations with our hunger exposure measure using the state of residence to identify the relevant occupation zone and the month of birth.

Generally, the boundaries of the three Western occupation zones were defined at the Yalta Conference in 1945 to coincide with borders of the pre-1937 states (Länder) which in turn coincide with the borders of the post-war states (Bundesländer) of the Federal Republic. The only exception is the region that in 1951 became Baden-Württemberg. As the majority of the population lived in the US zone (it contained the three largest cities Stuttgart, Karlsruhe and Mannheim), and as we only have information on the state where individuals lived in childhood according to the current 
boundaries, we assigned all those from Baden-Württemberg to the US zone.? See Appendix Table

A.1 for the definition of occupation zones.

We obtain information on the state of residence in childhood using several mechanisms. First, the SOEP contains a question in 2012 about the town in which the respondent was born. ${ }^{8}$ We obtain data on the corresponding state of residence and use this information for those individuals for which the state of residence can be matched to the indicated city with certainty. This information is available for 3,604 individuals (about $45 \%$ ) of the full sample.

Second, we construct a proxy of the state of residence at childhood using two further sources of information. The SOEP contains a question measuring whether the respondent is still living in the same city or area where he or she spent the majority of childhood up to age 15 . If the respondent indicates either "Yes, I still do" or "Yes, I have moved back," the respondent's current state of residence provides information on the state of residence in childhood (available for $51 \%$ of the full sample).

Furthermore, the SOEP collects information on the federal state of last school attendance (available for $46 \%$ of the full sample). We combine the information about the current residency matching the area of childhood as well as the state of school attendance and construct a measure

\footnotetext{
This assignment uncertainty implies that there is measurement error in the caloric intake variable. As only a relatively small fraction of the sample is affected, this error will be small. To assess its potential magnitude, we performed a robustness check by re-assigning all individuals from the state of Baden-Württemberg from the US to the French zone. We then re-estimated all regressions reported below in Table 3 using the caloric rations implied by the new zone assignment. The coefficients of the caloric rations variable change only marginally while the pattern of statistical significance across specification remains the same. The results are available in the Online Appendix in Table B.1.

${ }^{8}$ What city or town were you born in? If there is more than one town with the same name, please also state the name of the nearest city.

${ }^{9}$ The estimation sample does not differ substantially from the full sample in terms of mobility. We have information on whether individuals still live where they were raised for $98.46 \%$ of our estimation sample. About $60 \%$ still live where they were raised or have moved back, about $38 \%$ do not live there. In comparison, this information is missing for about $11 \%$ of the full 2003 sample; about $52 \%$ live there or have moved back and $37 \%$ do not live there. These figures do not suggest that differential mobility is a major concern. Moreover, our main results do not differ significantly for those living in the same area as in their childhood or for those with missing information on these variables. In a robustness test reported in the Online Appendix in Table B.2, we add dummy variables for these groups and their interactions with caloric rations and find no significant effects. Further, Bauer et al. (2013, p. 1004) write: "Despite the post-war confusion, the geographical mobility of natives appears to have been relatively low between 1939 and 1950 . According to the German population census of September 1950, the vast majority (95.9\%) of those who had lived in West Germany already before the war did not reallocate from one federal state to another between 1939 and 1950 .“
} 
for the state of residence in childhood giving the former information priority $(N=5,868)$. Comparing this proxy with the reliable state of birth obtained from wave 2012, we find that this information is consistent for about $87 \%$ of those individuals for which both information are available $(N=2,759)$. We focus on those for which information on the state of residence in childhood, data on the month of birth, and the trust measure are available $(N=6,503$, "hunger sample" hereafter). Note that during the hunger period (from 1945 to 1950), Germans were prohibited to relocate within the country (and abroad) by moving restrictions, so that moving in response to the caloric rations was not an option.

The average calorie measures are divided by 1000 , and their signs are reversed so that a higher value is associated with a higher exposure to lower caloric rations that would imply more hunger. For example, a change in average daily caloric rations within a specified period in childhood from 2000 to 1500 calories translates into a change from -2 to -1.5 in our transformed variable. To ensure the comparability of the caloric measures based on the average exposure to hunger and the variability in caloric rations, we also divided the standard deviation by 1000. In this respect a higher value is associated with a higher variability of caloric rations..$^{10}$

The data set is further enriched with background characteristics. The background measures contain information on the respondent's age, gender, whether growing up in an urban environment (equal to 1 if growing up in a large/medium/small city, equal to 0 if growing up in the countryside), the education level of both parents (higher degree if parent obtained secondary, intermediate, or upper secondary school degree), whether the respondent has any sibling, as well as the father's job position when the respondent was 15 years old (blue-collar, self-employed, white-collar, civil

\footnotetext{
${ }^{10}$ The correlation between the average caloric rations and the variability in caloric rations is 0.870 for age $0-16,0.579$ for age $0-3,0.650$ for age 4-7 and 0.812 for age $8-16$.
} 
service, died/not working). Table 1 provides descriptive statistics for the full and the hunger sample. We observe that the samples are very similar regarding their means and standard deviations.

\section{Results}

\section{Main findings}

We analyze the effect of caloric intake on trust using a variety of linear regressions estimated by OLS. The basic specification is

$$
Y_{i t r}=\alpha+\beta C R_{r t}+\delta_{r}+\gamma_{t}+\pi^{\prime} X_{i n}+\varepsilon_{i t},
$$

where $Y_{i t}$ is generalized trust measured in 2003 for individual $i$, born in region $r$ and period $t$. The regressor of interest is $C R_{n}$, the negative of the caloric intake in region $r$, averaged over a certain age period for an individual born in month $t$. We include region-specific fixed effects $\left(\delta_{r}\right)$, a month of birth trend $\left(\gamma_{1}\right)$, and additional controls $\left(X_{i n}\right)$. The error term $\varepsilon_{i t}$ is clustered by month of birth and region. As the outcome is measured at one point in time, we cannot separately identify age and cohort effects.

Table 2 presents the main results. In these regressions, exposure to hunger is based on caloric intake over ages 0-16. The first column displays the estimated raw association. Subsequent columns sequentially add explanatory variables. To control for age effects, we use a trend in the birth month, starting with a value of 1 for respondents born in January 1929 (which corresponds to the age restriction we impose on the sample). For respondents born in February 1929, the month of birth trend variable takes on the value of 2 etc. 
In column (2), we control for a quadratic of the birth month trend and dummies for different occupation zones. In column (3), we add general background characteristics: a gender dummy, a dummy for having grown up in an urban environment, as historically those living in urban areas where more severely affected by the post-war hunger episode, and they might also be different regarding trust in strangers. We also include controls for the respondent's socio-economic background proxied by indicators whether each parent has obtained a higher degree of education, whether an individual has any siblings, and the father's job position. Our previous research (Kesternich et al., 2015) shows that this hunger episode affected all socio-economic classes to the same extent. Strictly speaking, we do not need to control for socio-economic background. However, as we do not have individual-level measures of hunger, including these measures helps to control for differential trends across occupation zones in the socio-economic background that might also be related to trust." In column (4), we substitute the quadratic in the birth month trend with a more flexible specification with month-of-birth fixed effects.

In our main specification (column (3)), we find that experiencing hunger (lower caloric rations) significantly reduces our standardized measure for trust. In particular, a decrease in average daily caloric rations by $1000 \mathrm{kcal}$ decreases our standardized trust measure by 0.21 standard deviations (statistically significant at the 5 percent level). We observe caloric rations in the occupation zone corresponding to the state of residence in childhood at different ages of the respondent, but we do not observe whether an individual suffered from hunger. Moreover, individuals may have moved

\footnotetext{
"In addition, we investigated whether the effect of hunger on trust is confounded by whether the father was absent during childhood. We estimated a version of our main specification that includes a dummy variable for respondents whose father died before the age of fifteen. It turns out that neither the main effect nor its interaction with the caloric ration is statistically significant. The results are available in Table B.3 in the Online Appendix.
} 
out of the state of residence in childhood we constructed from the SOEP data. Thus, our estimates should be interpreted as intention-to-treat effects.

Moreover, we find that individuals in Eastern Germany exhibit less trust in strangers. Thus, there is a Soviet zone effect over and above the worse caloric rations. This effect, which does not change when we include family background measures, has been documented in the literature and interpreted as an effect of communism on preferences (Rainer and Siedler, 2009). Investigating our rich set of family background measures, we observe that individuals with a higher socioeconomic status, which can be seen both from the parents' educational background and the father's job position, exhibit more trust in strangers. These findings are in line with Gächter et al. (2004) who document that trust preferences are higher for individuals with higher socio-economic status. Furthermore, individuals with siblings appear to have significantly more trust in strangers. When we include month-of-birth fixed effects for the months between January 1929 and December 1955, the effect remains negative and similar in order of magnitude, but is not significant at the ten percent level any more (column (4)).

\section{Robustness checks}

We perform several robustness checks to investigate whether our findings might be explained by other variables that co-vary with caloric rations at childhood. We present the results of these analyses in Table 3. One concern is that our results might be driven by the Soviet occupation zone which has experienced, in many dimensions, more dramatic changes than the three western zones during our sample period. To confront this possibility, we conducted two robustness checks. First, we exclude those individuals who lived in the Soviet zone in the post-war period from our estimation sample in column (2). When we estimate the model without these individuals, the 
estimate of the coefficient of interest remains negative and significant. Second, we investigate whether our results are driven by differential time trends across zones. When we allow for zonespecific time trends using a linear month of birth trend, the estimate of the coefficient of interest remains negative and significant; see column (3) in Table 3.

In an additional robustness check, we include a dummy for all individuals who experience WWII (i.e., those born before May 1945) and a dummy for all individuals born during the hunger period (i.e., May 1945 through December 1950 for those living in the US, British or French occupation zone, and May 1945 through December 1957 for those living in the Soviet occupation zone). The results are presented in column (4) of Table 3. The effect of the caloric rations variable remains negative and significant. Being born before May 1945 has a positive and significant effect on trust, which is perhaps surprising but in line with recent research showing that war experiences might foster cooperation (Bauer et al., 2016). Being born during the hunger episode (i.e. after the end of the war and before December 1950) has a small positive, but insignificant coefficient.

A final open question is whether the level (i.e., the dramatic reduction) or the variance (i.e., insecurity) of calorie supply influences trust. In column (5), we include the standard deviation of our caloric rations measure. We find that the coefficient of the mean caloric rations remains significant and of similar magnitude, while the standard deviation has no significant effect on the trust measure. Thus, we conclude that it is the lack of food and not the variation in food supply that determines late-life trust.

Regarding alternative specifications of the time trend, we report third and fourth order polynomials in the month of birth trend (columns (6) and (7), respectively). The coefficient of the second and higher order terms of the age polynomials are never significant. The effect of our main regressor of interest remains negative, but is not statistically significant any more. Across all specifications 
shown in Table 3 , the point estimates range from -0.155 to -0.290 ; thus they are between 25 percent smaller and 41 percent larger (in absolute values) than in our preferred specification. The sign and order of magnitude of the point estimates always remain the same.

\section{Pathways between childhood exposure to hunger and adult trust}

We conjecture that the hunger episode has direct effects on trust preferences. Unlike the experience of bombing that seems to have strengthened a feeling of helping and trusting within the affected cities, ${ }^{12}$ the experience of extreme food shortage lead to a sense of everybody just fighting for their own survival. Predating the current discussion about trust and its determinants, in his historical analysis of post-war hunger episodes, Rothenberger (1980, p. 175) stresses that in a period of scarcity, when everybody had to fight for survival, "egoistic and querulous" traits crowded out social motivations. In addition, there was strong mistrust in Germany against the occupying governments who were thought to either not be doing their best to relieve the situation or even actively holding back on, or confiscating, food supplies (Schlange-Schöningen, 1955, p. 17ff). Historians call the food policies of the Allies one of "hardness and mistrust" (SchlangeSchöningen, 1955, p 18).

Several recent papers have shown that in the short run, experience of conflict tends to increase cooperation within those considered part of the own group, and evidence seems to point to a change in preferences rather than a pure change in economic payoffs (Bauer et al., 2016). Bauer et al. (2016) claim that intergroup competition should lead to more cooperation within the group. We also find evidence for this in the positive and significant coefficient of a dummy for having experienced WWII; see specification (4) of Table 3. However, when it comes to fighting for

${ }^{\prime}$ Friedrich (2002, p. 475) writes: "Everybody pulled everybody out of the rubble, emptied endangered flats, sprinkled with water, threw sand, demolished barracks and fences, the notorious fire-bridges" (our translation). Eitner (1990, p. 444) argues that Hitler's (theoretical) "peoples' community" (Volksgemeinschaft) became a (practical) community of suffering. 
resources, the hunger episode was not an intergroup but a within-group conflict, thus we would expect lower levels of trust also within the own countrymen. Our findings are also in line with recent findings on the effects of early childhood health in psychology. Petersen and Aarøe (2015) argue that "low birth weight is utilized as a forecast of a harsh environment, vulnerable condition, or both and, consequently, lowers social trust."

In addition to the direct effects of experiencing hunger on trust preferences, the hunger episode may influence trust through a number of indirect channels. The literature of the long-term effects of hunger has documented negative effects on health as well as education and labor market outcomes (Almond and Currie, 2011; Barker, 1992; Barker, 2004; Juerges, 2013; van den Berg et al., 2015). In Table 4, we report the results of regression models that explore some of these potential causal channels, following the ideas put forward in mediation analysis (see, for example, Baron and Kenny, 1986, and MacKinnon et al., 2007).

In Panel A of Table 4, we report reduced-form regressions of two health and one education measure: Being in the top 10 percentile of the number of doctor visits from the GSOEP, a standardized physical health measure (Andersen et al., 2007), and a dummy for a high level of education; descriptive statistics and details on the construction of these variables can be found in Appendix Table A.2. The results of these regressions indicate that experiencing periods of low caloric ration supply leads to significantly worse health outcomes and lowers the probability of having a high education level. Thus, both lower levels of health and education could be pathways from experiencing hunger to having lower levels of trust in adult life..$^{3}$

In Panel B of Table 4, specification (1) repeats our preferred specification from Table 2. In the remaining specifications (2)-(4), we added one pathway at a time and finally all pathways at once

Studies linking low levels of education and health to low trust levels include Alesina and Ferrara (2002) and Elgar (2010). 
in specification (5). We find that the coefficient of the caloric rations variable is about six percent smaller when including all pathways, but the difference is not significant. There is thus weak evidence at best that some of the effect of the hunger episode goes through health and education. However, a large part of the effect remains, suggesting that there are either large direct effects of experiencing hunger on trust or other pathways that we have not explored.

Note that the results from mediation analysis have to be taken with great care, for several reasons. First, we only have imperfect measures of health and education. Second, there may be many other potential channels that we do not include here. And third, as pointed out in the Angrist and Pischke (2014) discussion on bad controls, our estimates will not only be different when including possible channels because the effect that operates through the channel is now netted out, it also can lead to unwanted selection effects that bias the results.

\section{Exposure to hunger at different ages}

An important concern in the large literature on the effects of shocks experienced in early childhood on adult outcomes is the identification of "critical periods." In the psychological and experimental economics literatures, adolescence is put forward as an important period for the formation of social preferences and social behavior (van de Bos et al., 2010). Sutter and Kocher (2007) investigate trust and trustworthiness across different age groups. Their youngest age group consists of 8 year old children. They find that trust preferences are already present among 8 year olds, and that they strengthen until about age 20; thereafter, they are basically flat. Kocher (2015) suggests that adult levels of trust are reached at about 16 years of age. Unfortunately, none of the studies includes participants below 8 years of age. In our data, we also find an almost flat age profile of trust 
preferences among older individuals (see the insignificant month of birth terms in Table 3 as well as Figure B.1 in the Online Appendix).

In this section, we investigate whether there are critical periods for the long-run effects of hunger on trust, which has not been explored in the literature so far. Table 5 presents the coefficients from OLS regressions estimating the relationship between the respondent's willingness to trust and the average daily caloric intake at different ages in childhood (all ages 0-16 as well as specific ages 03, 4-7 and 8-16), including the full set of controls. The results for the four exposure ages are shown in columns (1) to (4). $\cdot^{14}$

We find the strongest effects for hunger experienced in childhood if we pool all ages. Investigating the specific age groups, we find stronger effects for hunger experienced as a child or in one's youth (at ages 4-7 and 8-16, respectively). The point estimates are largest in the oldest age group. However, the estimates are statistically significant at the 10 percent level only for exposure at ages 4-7. If we include the calorie measures for all specific age groups at the same time (column (5)), we observe a similar pattern and find significant effects only for the age group 4-7. For this age group, a decrease in average daily caloric rations by $1000 \mathrm{kcal}$ decreases our standardized trust measure by 0.05 standard deviations (statistically significant at the 10 percent level).

\section{Discussion and conclusion}

We have shown that respondents who were exposed to a hunger episode in post WWII Germany during their childhood and youth have lower levels of trust attitudes many years later. Investigating different definitions of exposure to hunger in childhood based on average caloric supply at the

\footnotetext{
"Note that our measures of experiencing hunger at different ages are correlated. The estimated pairwise correlation between experiencing hunger at age $0-3$ and $4-7$ is 0.536 , between age $0-3$ and 8-16 -0.308 and between 4-7 and 8-16 0.317. These estimates are statistically significant at $\mathrm{p}<$ 0.01 .
} 
regional and monthly level, we have shown that the general exposure to hunger rather than the variability of caloric rations was the key factor. The data on trust come from a random sample of the German population in 2003 while the historical exposure data refer to the hunger crisis in Germany after, and mostly immediately after, WWII. Hunger affected all regions and all socioeconomic classes, but caloric supplies showed substantial regional and temporal variation.

In order to clarify the interpretation of our findings, we would like to address three important issues. First, one might ask whether the effects of the caloric rations variable really capture the long-term effects of hunger or rather those of war (the latter have been established in a number of related studies, including Akbulut-Yuksel, 2014, and Kesternich et al., 2014). If the latter were the case, caloric rations would need to vary with war exposure. However, caloric rations varied across occupation zones and over time after the war. The variation in caloric rations reflects various factors that are related to the war but follow more complex regional and temporal patterns. As discussed above, the zone borders were artificially created. Moreover, the rations set by the allied occupation forces reflect the physical scarcity of food - due to the disruption of production caused by war destruction, by the creation of the artificial borders, and by the loss of the Eastern parts of the German Reich that traditionally used to be Germany's "bread basket.” Monthly variation in caloric rations over time was caused by weather conditions, by the influx of refugees, and most importantly by policy choices of the occupying governments. The latter is also related to the need and willingness to confiscate food, which happened mostly in the French and Soviet zones.

Second, it is conceivable that the variation in the caloric rations (and thus in hunger) is associated with other factors that influence trust, for example a shortage of heating fuels and an increase in crime rates, or the instability in family relations. As we are not aware of any data that would allow us to isolate the effects of such variables from the effect of hunger per se, one may interpret the 
effects we found as being generated by all these facets of the hardship individuals endure during severe hunger episodes.

Third, the hunger episode in Germany took place in a country that had been most profoundly affected by war, and many of whose cities lay in ruins. This may well have aggravated the effect of the hunger episode and might make its effects not comparable to other hunger episodes that take place under different circumstances.

Irrespective of these concerns, our results provide a new explanation for the substantial variation in trust preferences that has been observed in several studies. While previous research has shown that trust preferences can be altered in the short-run through the experience of violence, our data suggest that a large shock in a person's childhood can permanently alter trust preferences. While research has demonstrated that trust is a relatively stable adult trait (Caspi and Roberts, 2001), our research deals with the early childhood formation of trust. Its subsequent stability in adulthood is consistent with our perspective. Our results are also in line with other studies showing that childhood experiences can have long-run effects on preferences and expectations.

We discussed that trust plays an important role for human interactions both in the interpersonal and economic context. In light of our results, we would like to stress that the long-run consequences of war might be underestimated when being reduced to financial dimensions due to the destruction of buildings, infrastructure, businesses, and so forth. A further dimension to keep in mind should be "soft factors" like trust that affect interactions within society that play a role in the economic area (negotiations, transactions, teamwork at the workplace), but also the private area (interactions with neighbors, finding friends, finding a partner). The large-scale consequences of such shock-induced preference changes remain scope for future research. 
Our findings provide a new perspective on the seminal work of Barker (1992) who emphasizes that the largest impact of childhood nutrition shocks should be concentrated among the very young. However, Barker studies biological impacts of under-nutrition on health, while we emphasize the behavioral channel, namely, long-term effects on preferences. Our results can either mean that older ages are the sensitive periods for the foundation trust preferences, or that younger children were protected from the hunger episode. The former interpretation would be in line with recent evidence from Sutter and Koch (2007) who measure trust preferences at different ages and find that "trust increases almost linearly from early childhood to early adulthood." One has to note, though, that their study excludes the very young. The latter interpretation is consistent with very young children being better protected as they were still being breastfed.

This finding also adds to the discussion on long-terms effects of war and conflicts. First, experiments conducted around the 2006 Israel-Hezbollah War show that intra-group cooperation was increased during times of conflict. Here, we use a large random sample of a population to show that trust in strangers (in contrast to intra-group preferences as in Gneezy and Fessler, 2012) was decreased and that these effects were long-lasting and thus are still present more than 50 years after the experienced shock. Prior research on the long-term effects of WWII show that health, marriage, and labor market outcomes of those surviving are negatively affected (Juerges, 2013; Kesternich et al., 2014). If hardship that comes with violent conflicts, in our case hunger, permanently alters preferences, including trust, that are to a certain extent inherited within families (Dohmen et al., 2012; Ljunge, 2014), then this could perpetuate negative equilibria. 


\section{References}

Aarøe, L., M.B. Petersen. 2013. Hunger games: Fluctuations in blood glucose levels influence social welfare support. Psychological Science, 24(12), 2550-2556.

Akbulut-Yuksel, M. 2014. Children of war: The long-run effects of large-scale physical destruction and warfare on children. Journal of Human Resources, 49(3), 634-662.

Alesina, A., and E. La Ferrara. 2002. Who Trusts Others? Journal of Public Economics, 85(2), $207-234$.

Almond, D., J. Currie. 2011. Killing me softly: The fetal origins hypothesis. Journal of Economic Perspectives, 25(3), 153-172.

Andersen, H. H., Mühlbacher, A., Nübling, M., Schupp, J., \& Wagner, G. G. 2007. Computation of standard values for physical and mental health scale scores using the SOEP version of SF-12v2. Schmollers Jahrbuch, 127(1), 171-182.

Angrist, J. D. and S. Pischke, 2014. Mastering Metrics: The Path from Cause to Effect. Princeton, NJ: Princeton University Press.

Barker, D.J.P. 1992. Fetal and infant origins of adult disease. London: BMJ Publishing Group.

Barker, D.J.P. 2004. The developmental origins of adult disease. Journal of the American College of Nutrition, 23(6), 588S-595S.

Baron, R. M., \& Kenny, D. A. 1986. The moderator--mediator variable distinction in social psychological research: Conceptual, strategic, and statistical considerations. Journal of Personality and Social Psychology, 51(6), 1173.

Bauer, M., C. Blattman, J. Chytilová, J. Henrich, E. Miguel and T. Mitts. 2016. Can war foster 
cooperation? Journal of Economic Perspectives, 30(3), 249-74.

Bauer, M., A. Cassar, J. Chytilová, J. Henrich. 2014. War's enduring effects on the development of egalitarian motivations and in-group biases. Psychological Science, 25(1), 47-57.

Bauer, T. K., S. Braun, M. Kvasnicka. 2013. The economic integration of forced migrants: Evidence for Post-War Germany. Economic Journal, 123, 998-1024.

Bertoni, M. 2015. Hungry today, unhappy tomorrow? Childhood hunger and subjective wellbeing later in life. Journal of Health Economics, 40, 40-53.

Bigoni, M., S. Bortolotti, M. Casari, D. Gambetta, F. Pancotto. 2015. Amoral familism, social capital, or trust? The behavioral foundations of the Italian North-South divide. Economic Journal, forthcoming.

Black, S., P.J. Devereux, P. Lundborg, K. Majlesi. 2015. On the origins of risk-taking. Unpublished working paper.

Caspi, A., B.W. Roberts. 2001. Personality development across the life course: The argument for change and continuity. Psychological Inquiry, 12(2), 49-66.

Coleman, J.S. 1990. Foundations of social theory. Cambridge, MA: Belknap Press of Harvard University Press.

Dohmen, T., A. Falk, D.B. Huffman, U. Sunde. 2012. The intergenerational transmission of risk and trust attitudes. Review of Economic Studies, 79(2), 645-677.

Eitner, H.J. 1990. Hitlers Deutsche: Das Ende eines Tabus. Gernsbach: Katz.

Elder, G.H. 1998. The life course as development theory. Child Development 69(1), 1-12.

Elgar, Frank J. 2010. Income Inequality, Trust, and Population Health in 33 Countries. American 
Journal of Public Health 100(11), 2311-2315.

Farquharson, J.E. 1985. The Western allies and politics of food. Agrarian Management in Postwar Germany. Dover, NH: Berg Publishers.

Fehr, E., U. Fischbacher, B. von Rosenbladt, J. Schupp, G.G. Wagner. 2002. A nation-wide laboratory: Examining trust and trustworthiness by integrating behavioral experiments into representative surveys. Journal of Applied Social Science Studies, 122(4), 519-542.

Fehr, E., K. Hoff. 2011. Introduction: Tastes, castes and culture: The influence of society on preferences. Economic Journal, 121, F396-F412.

Friedrich, J. 2002. Der Brand: Deutschland im Bombenkrieg 1940-45. München: Propyläen.

Gächter, S., Herrmann, B., Thöni, C. 2004. Trust, voluntary cooperation, and socio-economic background: Survey and experimental evidence. Journal of Economic Behavior and Organization, 55, 505-531.

Gambetta, D. 2000. Can we trust trust? In: Gambetta, D. (Eds.). Trust: Making and Breaking Cooperative Relations Oxford: University of Oxford Press, 213-227.

Glaeser, E.L., D.I. Laibson, J.A. Scheinkman, C.L. Soutter. 2000. Measuring trust. Quarterly Journal of Economics, 115(3), 811-846.

Gneezy, A., D.M.T. Fessler. 2012. Conflict, sticks and carrots: War increases prosocial punishments and rewards. Proceedings of the Royal Society B: Biological Sciences, 279(1727), 219-223.

Goodman, A., R. Joyce, J.P. Smith. 2011. The long shadow cast by childhood physical and mental problems on adult life. Proceedings of the National Academy of Sciences, 108(15), 6032- 
6037.

Guiso, L., P. Sapienza, L. Zingales. 2008. Trusting the stock market. Journal of Finance 63(6), $2557-2600$.

Guiso, L., P. Sapienza, L. Zingales. 2009. Cultural biases in economic exchange. Quarterly Journal of Economics, 124(3), 1095-1131.

Juerges, H. 2013. Collateral damage: educational attainment and labor market outcomes among German war and post-war cohorts. Journal of Health Economics, 32, 286-303.

Kesternich, I., B. Siflinger, J.P. Smith, J. Winter. 2014. The effects of World War II on economic and health outcomes across Europe. Review of Economics and Statistics, 96(1), 103-118.

Kesternich, I., B. Siflinger, J.P. Smith, J. Winter. 2015. Individual behavior as a pathway between early-life shocks and adult health: Evidence from hunger episodes in post-war Germany. Economic Journal, 125, F372-F393.

Knack, S., P. Keefer. 1997. Does social capital have an economic payoff? A cross-country investigation. Quarterly Journal of Economics, 112, 1252-1288.

Kocher, M. G. 2015. How trust in social dilemmas evolves with age. In: Van Lange, P. A. M., Rockenbach, B., Yamagishi, T. (eds.). Social Dilemmas: New Perspectives on Trust, Oxford University Press, New York.

La Porta, R.F., F. Lopez-de-Silanes, A. Shleifer, R.W. Vishny. 1997. Trust in large organizations. American Economic Review, 87, 333-338.

Liebe, H., 1947. Drei Grundprobleme der deutschen Wirtschaft. In: Deutsches Institut fuer Wirtschaftsforschung (Eds.). Die deutsche Wirtschaft zwei Jahre nach dem 
Zusammenbruch. Tatsachen und Probleme. Berlin: Nauck.

Ljunge, M. 2014. Trust issues: Evidence on the intergenerational trust transmission among children of immigrants. Journal of Economic Behavior and Organization, 106, 175-196.

MacKinnon, D. P., Fairchild, A. J., \& Fritz, M. S. 2007. Mediation analysis. Annual Review of Psychology, 58, 593-614.

Malmendier, U., S. Nagel. 2011. Depression babies: Do macroeconomic experiences affect risktaking? Quarterly Journal of Economics 126, 373-416.

Malmendier, U., S. Nagel. 2016. Learning from inflation experiences. Quarterly Journal of Economics, forthcoming.

Malmendier, U., L.S. Shen. 2015. Experience effects in consumption. Unpublished working paper.

Naef, M., J. Schupp. 2009. Measuring trust: Experiments and surveys in contrast and combination. SOEP Papers on Multidisciplinary Panel Data Research 167 (The German SocioEconomic Panel (SOEP), Berlin).

Rainer, H., T. Siedler. 2009. Does democracy foster trust? Journal of Comparative Economics 37(2), 251-269.

Rothenberger, K., 1980. Die Hungerjahre nach dem Zweiten Weltkrieg. Boldt Verlag.

Petersen, M. B., L. Aarøe. 2015. Birth weight and social trust in adulthood: Evidence for early calibration of social cognition. Psychological Science, 26(11), 1681-1692.

Putnam, D., R. Leonardi, Y. Nanetti. 1994. Making democracy work: Civic traditions in modern Italy. Princeton University Press.

Schlange-Schöningen, H. 1955. Im Schatten des Hungers: Dokumentation zur Ernährungspolitik 
und Ernährungswirtschaft in den Jahren 1945-1949. Hamburg und Berlin: Verlag Paul Parey.

Schwarzer, O. 1995. Der Lebensstandard in der SBZ/DDR 1945/1989. Jahrbuch für Wirtschaftsgeschichte, Issue 2, 119-145.

Sutter, M., M. G. Kocher. 2007. Trust and trustworthiness across different age groups. Games and Economic Behavior, 59, 364-382.

van den Berg, G., P. J. Pinger, J. Schoch. 2015. Instrumental variable estimation of the causal effect of hunger early in life on health later in life. Economic Journal, 126, 465-506.

van den Bos, W., M. Westenberg, M., E. van Dijk, and E. A. Crone. 2010. Development of trust and reciprocity in adolescence. Cognitive Development, 25(1), 90-102. 


\section{Figures and Tables}

FIGURE 1: VARIATION OF CALORIC RATIONS OVER TIME AND OCCUPATION ZONES

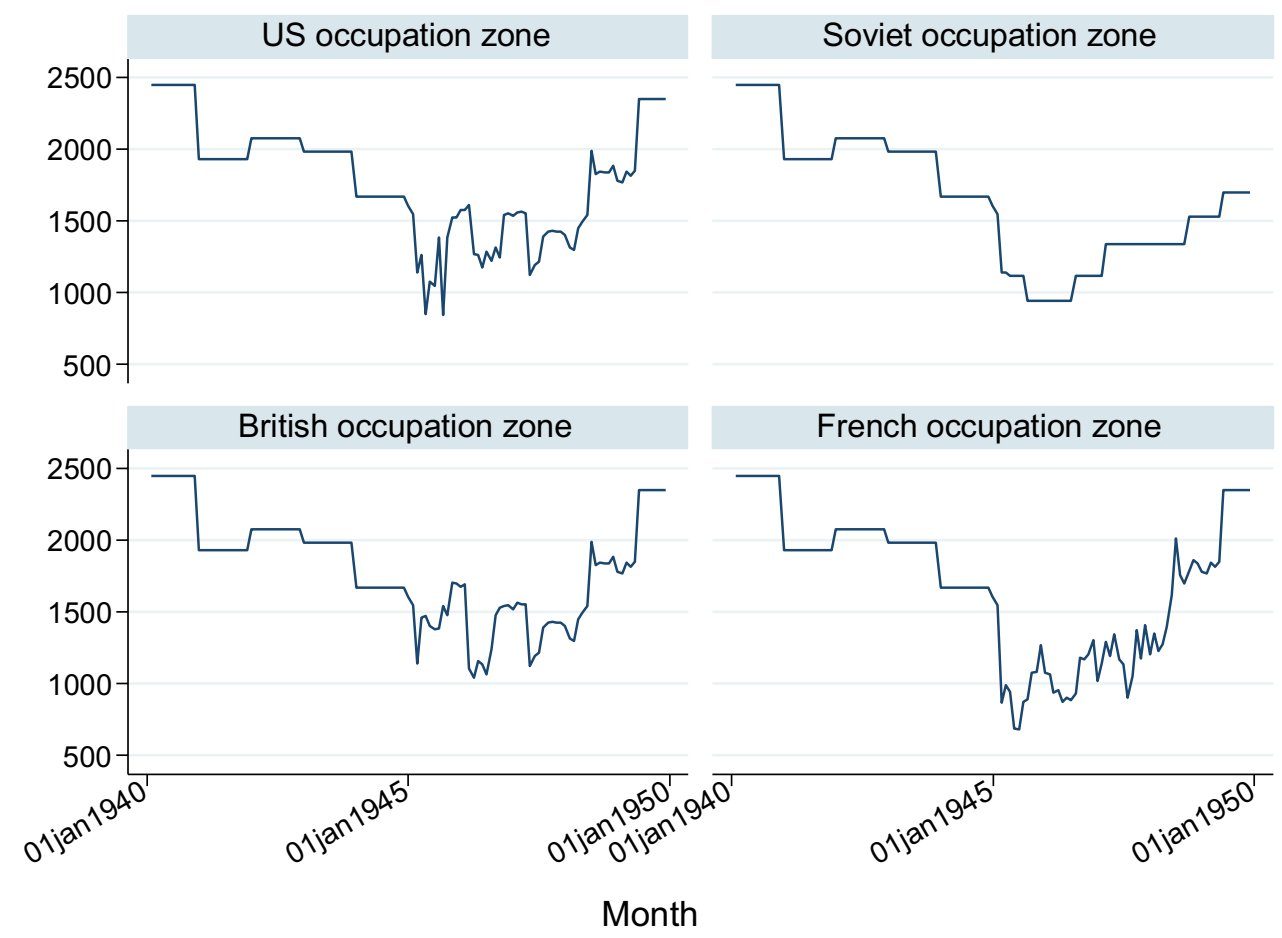

Notes: Figure displays average caloric rations per day for the four occupation zones. 
TABLE 1: DESCRIPTIVE STATISTICS

\begin{tabular}{|c|c|c|c|c|c|c|}
\hline \multirow[b]{2}{*}{ Variable } & \multicolumn{3}{|c|}{ Full sample } & \multicolumn{3}{|c|}{ Hunger sample } \\
\hline & $\mathbf{N}$ & Mean & SD & $\mathbf{N}$ & Mean & SD \\
\hline \multicolumn{7}{|l|}{ Outcome } \\
\hline Willingness to trust, PCA (std.) & 7854 & 0.00 & 1.00 & 6503 & 0.03 & 1.00 \\
\hline \multicolumn{7}{|l|}{ Calorie measures } \\
\hline (Negative) average daily caloric intake at age $0-16$ & & & & 6503 & -2.60 & 0.38 \\
\hline (Negative) average daily caloric intake at age 0-3 & & & & 6503 & -2.48 & 0.61 \\
\hline (Negative) average daily caloric intake at age 4-7 & & & & 6503 & -2.48 & 0.66 \\
\hline (Negative) average daily caloric intake at age 8-16 & & & & 6503 & -2.71 & 0.52 \\
\hline Standard deviation daily caloric intake at age $0-16$ & & & & 6503 & 0.47 & 0.28 \\
\hline Standard deviation daily caloric intake at age $0-3$ & & & & 6503 & 0.20 & 0.17 \\
\hline Standard deviation daily caloric intake at age 4-7 & & & & 6503 & 0.18 & 0.17 \\
\hline Standard deviation daily caloric intake at age 8-16 & & & & 6503 & 0.24 & 0.27 \\
\hline \multicolumn{7}{|l|}{ Control variables } \\
\hline Male & 7941 & 0.50 & 0.50 & 6503 & 0.51 & 0.50 \\
\hline Age & 7941 & 59.82 & 7.54 & 6503 & 59.26 & 7.36 \\
\hline Urban area (childhood) & 7795 & 0.60 & 0.49 & 6426 & 0.61 & 0.49 \\
\hline US zone (childhood) & 6713 & 0.27 & 0.44 & 6503 & 0.27 & 0.44 \\
\hline UK zone (childhood) & 6713 & 0.33 & 0.47 & 6503 & 0.33 & 0.47 \\
\hline French zone (childhood) & 6713 & 0.06 & 0.23 & 6503 & 0.06 & 0.24 \\
\hline Soviet zone (childhood) & 6713 & 0.34 & 0.47 & 6503 & 0.34 & 0.48 \\
\hline Father: Lower degree & 7231 & 0.80 & 0.40 & 5962 & 0.80 & 0.40 \\
\hline Father: Higher degree & 7231 & 0.20 & 0.40 & 5962 & 0.20 & 0.40 \\
\hline Mother: Lower degree & 7339 & 0.86 & 0.35 & 6041 & 0.85 & 0.36 \\
\hline Mother: Higher degree & 7339 & 0.14 & 0.35 & 6041 & 0.15 & 0.36 \\
\hline Any siblings & 7867 & 0.84 & 0.37 & 6454 & 0.84 & 0.37 \\
\hline Father: Blue-collar/agricultural & 6959 & 0.45 & 0.50 & 5803 & 0.45 & 0.50 \\
\hline Father: Self-employed & 6959 & 0.15 & 0.36 & 5803 & 0.16 & 0.37 \\
\hline Father: White-collar & 6959 & 0.19 & 0.40 & 5803 & 0.20 & 0.40 \\
\hline Father: Civil service & 6959 & 0.09 & 0.29 & 5803 & 0.09 & 0.29 \\
\hline Father: Died / not working & 6959 & 0.11 & 0.31 & 5803 & 0.10 & 0.31 \\
\hline
\end{tabular}

Notes: The full sample contains individuals that participated in wave 2003 of the SOEP, were born between 1929 and 1955 and have German nationality or immigrated prior to 1949 . The hunger sample contains individuals for which we can construct the trust measure and have data on the month of birth and state of residence in childhood via (1) reliable information about the state of birth contained in wave 2012 , or a proxy using (2) the state in which they spent the majority of their childhood up to the age 15 or, if not possible, (3) the state in which they last attended school. 
TABLE 2: OLS REGRESSION OF ADULT TRUST ON CHILDHOOD EXPOSURE TO HUNGER

\begin{tabular}{|c|c|c|c|c|}
\hline \multirow[b]{2}{*}{ Regressors } & \multicolumn{4}{|c|}{ Dependent variable: Adult trust } \\
\hline & (1) & (2) & (3) & (4) \\
\hline \multirow[t]{2}{*}{ (Negative) average daily caloric intake at age 0-16 } & $--.184 * * *$ & $--.180 * *$ & $--.206 * *$ & --.158 \\
\hline & $(.034)$ & $(.097)$ & $(.096)$ & $(.235)$ \\
\hline \multicolumn{5}{|l|}{ Basic controls } \\
\hline \multirow[t]{2}{*}{ Male } & & .006 & .002 & .014 \\
\hline & & $(.024)$ & $(.024)$ & $(.025)$ \\
\hline \multirow[t]{2}{*}{ Month of birth trend } & & .000 & --.001 & \\
\hline & & $(.001)$ & $(.001)$ & \\
\hline \multirow[t]{2}{*}{ (Month of birth trend) $)^{2}$} & & --.000 & .000 & \\
\hline & & $(.000)$ & $(.000)$ & \\
\hline \multirow[t]{2}{*}{ US zone (childhood) } & & .016 & .013 & .013 \\
\hline & & $(.030)$ & $(.030)$ & $(.025)$ \\
\hline \multirow[t]{2}{*}{ French zone (childhood) } & & --.045 & --.029 & --.035 \\
\hline & & $(.057)$ & $(.057)$ & $(.054)$ \\
\hline \multirow[t]{2}{*}{ Soviet zone (childhood) } & & $--.172 * * *$ & $--.144 * * *$ & $--.157 * * *$ \\
\hline & & $(.038)$ & $(.038)$ & $(.058)$ \\
\hline \multirow[t]{2}{*}{ Urban area (childhood) } & & & .022 & .013 \\
\hline & & & $(.028)$ & $(.029)$ \\
\hline \multirow[t]{2}{*}{ Urban area missing (childhood) } & & & $.176^{*}$ & .150 \\
\hline & & & $(.106)$ & $(.110)$ \\
\hline \multicolumn{5}{|l|}{ Family background } \\
\hline \multirow[t]{2}{*}{ Mother: Higher degree } & & & $.139 * *$ & $.129 * * *$ \\
\hline & & & $(.042)$ & $(.044)$ \\
\hline \multirow[t]{2}{*}{ Father: Higher degree } & & & $.138 * * *$ & $.141 * * *$ \\
\hline & & & $(.038)$ & $(.039)$ \\
\hline \multirow[t]{2}{*}{ Any siblings } & & & $.061 *$ & .050 \\
\hline & & & $(.036)$ & $(.036)$ \\
\hline \multirow[t]{2}{*}{ Father: Self-employed } & & & $.115^{* * *}$ & $.125^{* * *}$ \\
\hline & & & $(.039)$ & $(.041)$ \\
\hline \multirow[t]{2}{*}{ Father: White-collar } & & & $.169 * * *$ & $.172 * * *$ \\
\hline & & & $(.037)$ & $(.040)$ \\
\hline \multirow[t]{2}{*}{ Father: Civil service } & & & $.153 * * *$ & $.161 * * *$ \\
\hline & & & $(.046)$ & $(.048)$ \\
\hline \multirow[t]{2}{*}{ Father: Died/not working } & & & $.134 * * *$ & $.140 * * *$ \\
\hline & & & $(.045)$ & $(.046)$ \\
\hline \multirow[t]{2}{*}{ Father: Missing job position } & & & $--.102 * *$ & $--.092 *$ \\
\hline & & & $(.047)$ & $(.049)$ \\
\hline Month of birth trend FE & & & & Yes \\
\hline $\mathbf{N}$ & 6503 & 6503 & 6503 & 6503 \\
\hline \multicolumn{5}{|c|}{$\begin{array}{l}\text { Notes: Values are estimated coefficients (SE) based on the hunger sample. The standardized principal component of agreemen } \\
\text { with trust questions in } 2003 \text { (general trust, reliance on others, need for caution in dealing with strangers) is used as the dependen } \\
\text { variable. The regressions in column } 3 \text { and } 4 \text { contain dummies for missing observations in parents' education and siblings that are } \\
\text { all insignificant. The reference group for the father's job position is blue-collar/agricultural. All estimates are based on OLS } \\
\text { regressions with robust standard errors clustered at the month of birth } \times \text { occupation zone at childhood level. } \\
\text { *** Significant at the } 1 \text { percent level. } \\
\text { ** Significant at the } 5 \text { percent level. } \\
* \text { Significant at the } 10 \text { percent level. }\end{array}$} \\
\hline
\end{tabular}


TABLE 3: ROBUSTNESS CHECKS

\begin{tabular}{|c|c|c|c|c|c|c|c|}
\hline Regressors & Baseline & $\begin{array}{c}\text { Excluding } \\
\text { Soviet zone }\end{array}$ & $\begin{array}{l}\text { Interaction } \\
\text { month of } \\
\text { birth trend } x \\
\text { occupation } \\
\text { zones } \\
\text { (3) }\end{array}$ & WWII & $\begin{array}{c}\text { Variation } \\
\text { in caloric } \\
\text { intake }\end{array}$ & $\begin{array}{c}3^{\text {rt }} \text { order } \\
\text { polynomial } \\
\text { in month of } \\
\text { birth trend }\end{array}$ & $\begin{array}{c}4^{\text {th }} \text { order } \\
\text { polynomial } \\
\text { in month of } \\
\text { birth trend }\end{array}$ \\
\hline \multirow[t]{2}{*}{$\begin{array}{l}\text { (Negative) average daily caloric } \\
\text { intake at age } 0-16\end{array}$} & $--.206^{* *}$ & $--.254 * *$ & $--.220 * * *$ & $--.290 * *$ & $--.213 * *$ & --.155 & --.285 \\
\hline & $(.096)$ & $(.121)$ & $(.066)$ & $(.143)$ & $(.097)$ & $(.205)$ & $(.239)$ \\
\hline $\begin{array}{l}\text { Standard deviation daily caloric } \\
\text { intake at age } 0-16\end{array}$ & & & & & $\begin{array}{c}.076 \\
(.116)\end{array}$ & & \\
\hline Month of birth trend & $\begin{array}{l}--.001 \\
(.001)\end{array}$ & $\begin{array}{l}--.001 \\
(.001)\end{array}$ & $\begin{array}{l}--.001 \\
(.000)\end{array}$ & $\begin{array}{l}--.001 \\
(.001)\end{array}$ & $\begin{array}{l}--.001 \\
(.001)\end{array}$ & $\begin{array}{l}--.002 \\
(.004)\end{array}$ & $\begin{array}{l}--.003 \\
(.004)\end{array}$ \\
\hline$(\text { Month of birth trend) })^{2}$ & $\begin{array}{c}.000 \\
(.000)\end{array}$ & $\begin{array}{c}.000 \\
(.000)\end{array}$ & & $\begin{array}{c}.000 \\
(.000)\end{array}$ & $\begin{array}{c}.000 \\
(.000)\end{array}$ & $\begin{array}{c}.000 \\
(.000)\end{array}$ & $\begin{array}{c}.000 \\
(.000)\end{array}$ \\
\hline US zone (childhood) & $\begin{array}{c}.013 \\
(.030)\end{array}$ & $\begin{array}{c}.003 \\
(.030)\end{array}$ & $\begin{array}{l}--.021 \\
(.072)\end{array}$ & $\begin{array}{c}.013 \\
(.030)\end{array}$ & $\begin{array}{c}.012 \\
(.030)\end{array}$ & $\begin{array}{c}.012 \\
(.030)\end{array}$ & $\begin{array}{c}.013 \\
(.030)\end{array}$ \\
\hline French zone (childhood) & $\begin{array}{l}--.029 \\
(.057)\end{array}$ & $\begin{array}{l}--.039 \\
(.057)\end{array}$ & $\begin{array}{l}--.132 \\
(.133)\end{array}$ & $\begin{array}{l}--.025 \\
(.057)\end{array}$ & $\begin{array}{l}--.032 \\
(.057)\end{array}$ & $\begin{array}{l}--.031 \\
(.057)\end{array}$ & $\begin{array}{l}--.025 \\
(.057)\end{array}$ \\
\hline Soviet zone (childhood) & $\begin{array}{c}--.144 * * * \\
(.038)\end{array}$ & & $\begin{array}{c}--.195^{* * * *} \\
(.070)\end{array}$ & $\begin{array}{c}--.142 * * * \\
(.050)\end{array}$ & $\begin{array}{c}--.147 * * * \\
(.038)\end{array}$ & $\begin{array}{c}--.155^{* * * *} \\
(.055)\end{array}$ & $\begin{array}{c}--.127 * * \\
(.061)\end{array}$ \\
\hline Month of birth trend $\mathrm{x}$ US zone & & & $\begin{array}{c}.000 \\
(.000)\end{array}$ & & & & \\
\hline $\begin{array}{l}\text { Month of birth trend x Soviet } \\
\text { zone }\end{array}$ & & & $\begin{array}{c}.000 \\
(.000)\end{array}$ & & & & \\
\hline $\begin{array}{l}\text { Month of birth trendx French } \\
\text { zone }\end{array}$ & & & $\begin{array}{c}.001 \\
(.001)\end{array}$ & & & & \\
\hline (Month of birth trend) $)^{3}$ & & & & & & $\begin{array}{l}--.000 \\
(.000)\end{array}$ & $\begin{array}{l}--.000 \\
(.000)\end{array}$ \\
\hline (Month of birth trend) ${ }^{4}$ & & & & & & & $\begin{array}{c}.000 \\
(.000)\end{array}$ \\
\hline Born before May 1945 & & & & $\begin{array}{l}.181 * * \\
(.087)\end{array}$ & & & \\
\hline $\begin{array}{l}\text { Born after WWII, but before } \\
\text { end of hunger episode }\end{array}$ & & & & $\begin{array}{c}.066 \\
(.059)\end{array}$ & & & \\
\hline Further controls & Yes & Yes & Yes & Yes & Yes & Yes & Yes \\
\hline $\mathbf{N}$ & 6503 & 4266 & 6503 & 6503 & 6503 & 6503 & 6503 \\
\hline
\end{tabular}

Notes: Values are estimated main coefficients (SE) based on the hunger sample. Further controls include gender, growing up in an urban environment, whether each parent has obtained a higher degree (defined as intermediate, technical, or upper secondary school degree), having any siblings, job position of father (blue-collar/agricultural (reference), self-employed, white-collar, civil service, died/not working). All estimates are based on OLS regressions with robust standard errors clustered at the month of birth $\times$ occupation zone at childhood level.

*** Significant at the 1 percent level.

** Significant at the 5 percent level.

* Significant at the 10 percent level. 
TABLE 4: POTENTIAL PATHWAYS BETWEEN CHILDHOOD EXPOSURE TO HUNGER AND ADULT TRUST

\begin{tabular}{|c|c|c|c|c|c|}
\hline & & $\begin{array}{c}\text { More than } 7 \\
\text { doctor visits } \\
\text { in past } 3 \\
\text { months }\end{array}$ & $\begin{array}{c}\text { Physical } \\
\text { health score }\end{array}$ & $\begin{array}{l}\text { High degree } \\
\text { in education }\end{array}$ & \\
\hline Regressors & (1) & (2) & (3) & (4) & (5) \\
\hline \multicolumn{6}{|l|}{ Panel A (dependent variables: pathways) } \\
\hline \multirow[t]{2}{*}{$\begin{array}{l}\text { (Negative) average daily caloric intake } \\
\text { at age } 0-16\end{array}$} & & .042 & $--1.788 *$ & $--.143 * * *$ & \\
\hline & & $(.027)$ & $(.941)$ & $(.044)$ & \\
\hline \multicolumn{6}{|c|}{ Panel B (dependent variable: adult trust) } \\
\hline \multirow[t]{2}{*}{$\begin{array}{l}\text { (Negative) Average daily caloric } \\
\text { intake at age } 0-16\end{array}$} & $--.206 *$ & $--.189 * *$ & $--.230 * *$ & $--.168 *$ & $--.194 * *$ \\
\hline & $(.096)$ & $(.095)$ & $(.097)$ & $(.095)$ & $(.096)$ \\
\hline \multirow[t]{2}{*}{$\begin{array}{l}\text { More than } 7 \text { doctor visits in past } 3 \\
\text { months }\end{array}$} & & $--.248 * * *$ & & & $--.149 * * *$ \\
\hline & & $(.043)$ & & & $(.044)$ \\
\hline \multirow[t]{2}{*}{ Physical health score } & & & $.013^{* * *}$ & & $.010^{* * *}$ \\
\hline & & & $(.001)$ & & $(.001)$ \\
\hline \multirow[t]{2}{*}{ High degree in education } & & & & $.311 * * *$ & $.268^{* * *}$ \\
\hline & & & & $(.027)$ & $(.028)$ \\
\hline Further controls & Yes & Yes & Yes & Yes & Yes \\
\hline $\mathrm{N}$ & 6503 & 6477 & 6254 & 6496 & 6226 \\
\hline
\end{tabular}

Notes: Values are estimated coefficients (SE) based on the hunger sample. The regression in the first column is identical to the regression in column 3 of Table 2. Further controls include gender, month of birth trend and (month of birth trend)', growing up in an urban environment, occupation zone fixed effects, whether each parent has obtained a higher degree (defined as intermediate, technical, or upper secondary school degree), having any siblings, job position of father (bluecollar/agricultural (reference), self-employed, white-collar, civil service, died/not working). All estimates are based on OLS regressions with robust standard errors clustered at the month of birth $\times$ occupation zone at childhood level.

*** Significant at the 1 percent level.

** Significant at the 5 percent level.

* Significant at the 10 percent level. 
TABLE 5: ROLE OF CHILDHOOD EXPOSURE TO HUNGER AT DIFFERENT AGES

\begin{tabular}{|c|c|c|c|c|c|}
\hline \multirow[b]{2}{*}{ Regressors } & \multirow{2}{*}{$\begin{array}{c}\text { All ages } \\
\text { (1) }\end{array}$} & \multicolumn{3}{|c|}{ Specific ages (infant, child, youth) } & \multirow{2}{*}{$\begin{array}{c}\text { Joint } \\
\text { estimation } \\
(5)\end{array}$} \\
\hline & & (2) & (3) & (4) & \\
\hline (Negative) average daily caloric intake at age $0-16$ & $\begin{array}{c}--.206^{* *} \\
(.096)\end{array}$ & & & & \\
\hline (Negative) average daily caloric intake at age $0-3$ & & $\begin{array}{c}.023 \\
(.035)\end{array}$ & & & $\begin{array}{l}--.020 \\
(.051)\end{array}$ \\
\hline (Negative) average daily caloric intake at age $4-7$ & & & $\begin{array}{c}--.055^{*} \\
(.029)\end{array}$ & & $\begin{array}{c}--.050 * \\
(.030)\end{array}$ \\
\hline (Negative) average daily caloric intake at age $8-16$ & & & & $\begin{array}{l}--.098 \\
(.063)\end{array}$ & $\begin{array}{l}--.117 \\
(.092)\end{array}$ \\
\hline Further controls & Yes & Yes & Yes & Yes & Yes \\
\hline $\mathrm{N}$ & 6503 & 6503 & 6503 & 6503 & 6503 \\
\hline
\end{tabular}

Notes: Values are estimated main coefficients (SE) based on the hunger sample. Further controls include gender, month of birth trend and (month of birth trend)' , growing up in an urban environment, occupation zone fixed effects, whether each parent has obtained a higher degree (defined as intermediate, technical, or upper secondary school degree), having any siblings, job position of father (blue-collar/agricultural (reference), self-employed, white-collar, civil service, died/not working). All estimates are based on OLS regressions with robust standard errors clustered at the month of birth $\times$ occupation zone at childhood level.

*** Significant at the 1 percent level.

** Significant at the 5 percent level.

* Significant at the 10 percent level. 


\section{Appendix}

APPENDIX TABLE A.1: DEFINITION OF OCCUPATION ZONES

\begin{tabular}{llll}
\hline \hline US zone & Soviet zone & British zone & French zone \\
\hline Bremen & Berlin & Schleswig-Holstein & Rhineland-Palatinate \\
Hesse & Brandenburg & Hamburg & Saarland \\
Baden-Wuerttemberg & Mecklenburg Western Pomerania & Lower Saxony & \\
Bavaria & Saxony & North Rhine-Westphalia & \\
& Saxony-Anhalt & & \\
& Thuringia & & \\
& GDR, without further details & & \\
\hline \hline
\end{tabular}


APPEndiX TABle A.2: DesCRIPTIVE STATISTICS OF PATHWAYS

\begin{tabular}{lccc}
\hline \hline & \multicolumn{3}{c}{ Hunger sample } \\
Variable & N & Mean & SD \\
\hline Pathways & 6477 & 0.09 & 0.29 \\
More than 7 doctor visits in past 3 months & 6254 & 47.01 & 9.74 \\
Physical health score & 6496 & 0.53 & 0.50 \\
High degree of schooling & & & \\
\hline \hline
\end{tabular}

Notes: More than 7 doctor visits is an indicator constructed from information on the number of doctor visits in past 3 months in SOEP wave 2003, marking the highest decile. Physical health score combines questions from the SF-12v2 inventory contained in SOEP wave 2002. A higher value indicates better health. High degree of schooling indicates that respondent has obtained an intermediate/technical or upper secondary school degree (collected via biography questionnaire). 